\title{
DECONSTRUCTION OF FINANCIAL REPORT PURPOSES BASED ON INDONESIAN ECONOMIC SYSTEM: MOHAMMAD HATTA'S DEMOCRATIC ECONOMIC PERSPECTIVE
}

\author{
Putra Nugraha Adi ${ }^{\star}$, Triyuwono Iwan, Ludigdo Unti \\ Faculty of Economics and Business, University of Brawijaya, Malang, Indonesia \\ *E-mail: nugrahaadiputra@gmail.com
}

\begin{abstract}
This study intends to make alternative forms concept of financial reporting purposes. Forms of new financial reporting purposes are deconstructed according democratic economic (Indonesian's economy system). The research method used is qualitative with postmodernism as paradigm and deconstruction as a method. In making the construct, researchers extract Mohammad Hatta's thoughts and get three values. The values found are unity, government role, and divinity. This study produces a form of financial reporting that presents financial information with the aim of providing a sense of unity that accommodates the information needs of economic policy and means of worshiping to God for entities, workers, government, and investors.
\end{abstract}

\section{KEY WORDS}

Financial reporting, accounting, capitalism, democratic economic, deconstruction.

The purpose of financial reporting is the basis of the conceptual framework which is further used in the design of financial reporting standards. This is reflected in the conceptual framework of International Finance Reporting Standard / IFRS which was then adopted into Pernyataan Standar Akuntansi Keuangan / PSAK (Statement of Financial Accounting Standards of Indonesia) in 2005 by Indonesia. IFRS is the result of the Lisbon agreement. One of which is the strengthening of the EU economy implemented through the European Parliament and Council Regulation No. 1606 dated on 2002 July 19 (Palea, 2015). Financial reporting is intended to accommodate investors and protect them (see EPCR 1606 sections 1,2 , and 4 ). The dominant role of financiers as the main actors in financial reporting reflects capitalism in accounting (Palea, 2015).

The purpose of financial reporting of capitalism is not without problems. According Mulawarman (2012) western capitalism has been "trapped" in the accounting arbitrariness and madness of capital ruler through entities to always be their most effective and efficient tool. Financial reporting of accounting results such as this dehumanizing human into "economic animals" as Triyuwono (2006) to gain profit as much as possible. Physically, capitalism in accounting will bring about a circular economic crisis due to the game of speculation. Crisis is the basic nature of capitalism which is a scourge for the country that implements it (Hamid, 2009). So financial reporting like this allegedly brings moral damage in the form of greed and physical damage in the form of a circular economic crisis.

The influence of the economic system of capital in financial reporting purposes to be biased if confronted with Indonesia's economic system. The economic system in Indonesia sees that the economy is structured as a joint effort based on kinship (Article 33 paragraph 1 of the 1945 Constitution). The economic system implemented in Indonesia known as the democratic economic (ekonomi kerakyatan). The originator was Mohammad Hatta, Indonesia's first vice president. Democratic economic have three main values are: unity, government role, and divinity.

The intellectual coercion of capitalism into the accounting dimension in Indonesia has become a growing topic in academia. Some researchers, such as Sitorus (2015), Triyuwono (2006), and Ludigdo (2012) see that the accounting that developed deviated from the values adopted by Indonesia, ideologically, definition (Sitorus, 2015), religion (Triyuwono, 2006) , and professional ethics (Ludigdo, 2012). The idea to deconstruct the accounting in Indonesia 
continues to grow. This is triggered by dissatisfaction with the ability of capitalist economics to answer economic problems (including accounting) like what is being discussed by Mubyarto (1987) for decades. Research is continuing previous researchers to continue to criticize the accounting development in Indonesia.

One of the most critically acclaimed accounting dimensions is its purpose. Accounting objectives are directly textual written within the conceptual framework of financial reporting standards. Referring to Mubyarto (1987) who sees that joint economic development should be run with local knowledge, the objective of financial reporting is acceptable as long as it is in accordance with the values and national identity (Mulawarnan, 2011). So the optimal design of a financial report should depend on the characteristic of a specific economic and political system (Palea, 2015). For that purpose, this research is made to develop the concept of financial reporting objectives that are in line with the democratic economic system adopted by Indonesia.

\section{LITERATURE REVIEW}

Democratic Economic is a combination of the concept of world-famous economic system (capitalist and socialist) that is mixed by Mohammad Hatta that becomes a unique economic concept. The democratic economic born out from Mohammad Hatta's surfait due to Indonesian economic and social conditions at that time. The definition of a populist economy is an economic situation in which various economic activities are organized by involving the participation of all members of society, while the implementation of economic activities is under the control of the people. There are two main elements in the democratic economy and prosperity (Baswir, 1997: 4).

"Economics is the science that expresses an orderly knowledge of causal relationships and on the various problems that are seen around human goals to achieve prosperity" (Hatta, 1935).

"The economy comes from the words of Grik (Greek): oikos (house) and nomos (science). That is the science that governs the household. Household is only well organized, if spending money is arranged in such a way as to spend it, so as to achieve with it the greatest satisfaction. Not only do people have to save money, organize the spending as well as possible between today and the next day "(Hatta, 1935).

The quote above is Mohammad Hatta's thought about what an economy is derived from his writings entitled "Economy and Prosperity (1935)". Economics is about achieving a more perfect life. Economics is basically a struggle to live in the insistence of nature. Man does not live if he does not eat, does not eat if he does not try (Hatta, 1935).

In his life, human beings are faced with the need for constant satisfaction. The level of human satisfaction with the means of satisfying needs increases with increasing progress, society, and intelligence. The necessities of human life can be said to be infinite (Hatta, 1935).

When humans are confronted with an infinite need whether it will make people greedy and trying to scoop up the means of satisfying the greatest need? The answer is no, like the quote below:

"Such is the behavior of human need and the satisfaction of each of its goods. The more the amount of stuff to it, the less it feels. This fact is called in the economy: the law for the less. It is also called the first Gossen Law "(Hatta, 1935).

Mohammad Hatta emphasized that the human concept has been satisfied with the "as it is" needs satisfaction tool. If a need already have enough satisfied, then the satisfaction tool that comes later becomes less useful value or even become useless.

For Mohammad Hatta man is a social creature. As stated in the following quotation:

"And in that do not forget, that man never lives alone. Except in circumstances that force, like Robinson Crusoe on the island. Also Robinson who is remote and living with a self is coming from a crowded society. Humans are social beings. Since the world of human development has been found to live in villages "(Hatta 1935). 
Man cannot be separated from other human beings. Humans live in a circle of civilizations with other humans. So also in meeting the daily needs and achieve prosperity, humans need other human beings. The level of prosperity is built by the society in which the human is born. The higher the civilization of society the higher the level of prosperity that must be achieved.

This social nature of human beings seems to be a contradiction to the economic activities that each human being is doing. Hunger, thirst, shelter and other necessities are attached to individual human beings (meaning humans have no collective need) and this economic ambiguity that will affect the attitudes and economic motives of each person. Therefore, they themselves should be able to fulfill it all not others (Hatta, 1935).

According to Mohammad Hatta (1935) economic law is attached to the human self individually. However, people live in society. The first thing to remember is that economic law is eternal throughout human life but the nature of economic law is the same as other laws that can change due to environmental factors, circumstances, national culture, state law, social organizations, ideals society and religion, moral and moral strength of the nation. The goal of achieving prosperity (economic law) is attached to the human self individually but the purpose of prosperity is influenced by society (social law). The concept of a balance between the values contained in the economy and the human need to live together as a social creature that eventually became the forerunner of Mohammad Hatta's thoughts on democratic economic.

Mohammad Hatta sees that Indonesia's rupture is in an age of economic crisis (Hatta, 1934). Crisis arising from capitalism which became the inheritance system of Dutch colonial a bag of Indonesia for 350 years. Capitalism is allegedly causing socio-economic classes, the elimination of government roles, and the elimination of God as the center of accountability. Democratic economic is a form of immunization created by Mohammad Hatta for Indonesia to avoid capitalist understanding. The three main values possessed by the populist economy which is the main ingredient to ward off the "disease" is the value of economic class unity, the value of the government's role, and the value of the divine.

The value of unity speaks of tearing down the social-economic vertical class formed from the economic system of capitalism into a horizontal role group. The value of government talks about the role of government in a parental economy. The divine value speaks of God's role as the center of human responsibility. These three values are extracted from Mohammad Hatta's thought which is believed to ward off capitalism. This study uses these three values in deconstructing the purpose of financial reporting.

\section{METHODS OF RESEARCH}

This research uses qualitative research methodology with postmodernism paradigm to answer problem arising from phenomenon. The problems that have occurred are entrenched strongly and not enough just to give suggestions and criticism. For that it is necessary to present a new form by destroying or by leaving a little old form. This process is called deconstruction. According Triyuwono (2012: 372-374) deconstruction is an effort to present other aspects that are beyond the big narrative. Deconstruction is often described as skeptical and destructive, such as dismantling a building in the sense that after being disassembled and then reassembled as the philosopher Jaques Derrida "deconstruire" which in French means "to dismantle the machine" (O'Donnell, 2003: 58).

This research uses Mohammad Hatta's thoughts on the economy. According to Kamayanti (2016: 189), Saharuddin (2009), and Wagiran (2011), researchers (especially non-positivist researchers) have the freedom to use local thought and wisdom into a methodology. Local thinking and wisdom are relevant to addressing local issues. In this study, Mohammad Hatta's thought was used as a "new value" which was incorporated as a new construct-building instrument (democratic economic) with the old construct (capitalism) as the foundation. 


\section{DISCUSSION OF RESULTS} divinity.

Democratic economic is built on three main values of unity, government role, and

Unity. Mohammad Hatta (1933a) sees the Indonesian people divided into three societal economic structures: 1) The large capital class consists of the West; 2) The middle class ( middlestand) consisting of Chinese, Arab, Bombai, and other Central Asian peoples; and 3) The marhaen class, the lower class of workers and the poor whose content is dominated by most Indonesians.

The large capital class has no obstacles in achieving prosperity because it has good economic capability in the production and distribution. The middle class (middlestand) is a mutual trade partnership in the conduct of production and distribution supported by large capital classes. The combination of large capital class and the middle class (middlestand) this makes marhaen depressed in the economy class (Hatta, 1933a).

The proper way to counter socio-economic class form is to unite it. The trick is to break down the horizontal class and turn it into a vertical group based on the properties of the work (Hatta, 1932). As stated in the following quotation:

"We do not deny that in our social circle there are also groups like peasants, workers (rough and smooth) and merchants" (Hatta, 1932).

"To find the unity of Indonesia that has no class we do not need to blend the peasants, our workers and our merchants become one of the same people. That certainly will not be there. While humans live the differences in skills and differences in nature will not disappear. And that difference is necessary to make a division of work! Only we must work, so that the differences of the people should not be the difference and the opposition of the economic class. The difference must be restored to the difference of beroep, the difference role" (Hatta, 1932).

The nature of the work is classified into three groups namely: 1) Group of producers; 2) consumer category; 3) Group of distributors (Hatta, 1933b). Then each of these groups build cooperatives and cooperate with each other to fight against the economic power of the invaders. After the invaders leave, it is expected that the people have mastered 3 major aspects in the economy ie production, consumption, and distribution. With this aspiration Mohammad Hatta to see people who are economically independent can be achieved.

The form of economic unity that is expected to emerge in the people's economic system is the synergy of all groups. From the example given by Mohammad Hatta are the merchants (the big capital and the middle stand) helping the people by lowering prices and selling the product of the peasants and workers (the marhaen) which will affect the purchasing power of the people. The high purchasing power of the people will again be an advantage for the merchants. This synergy which Mohammad Hatta wants to highlight is summed up as an altruistic form, a trait to help each other without reward. Nevertheless, the roles still get results according to what he does. So there is a sense of fairness for each group.

The Role of Government. As a country that still "creeps" in economy, the government has a big share in improving the economy. In the paradigm of populist economy, the government has three main functions namely educating (Noer, 2012: 41), supervising, and building from above (Hatta, 1977). According to Baswir (2009) the way the democratic economic places the government in the economic system is the antithesis of the capitalist system that discards the role of government outside (see Triyuwono et al. (2016: 257); Smith (1976); and Kennedy (2009)). Democratic economic cannot be equated with the Keynesianism that makes the government born from class crackdown and stands as the center of economic control (Turner, B eeghley, and Powers, 1981: 165). It could be said, the democratic economic system that stands in the middle of the two forms of this economic (Baswir, 2009).

The type of Indonesian economic system is a guided economy (Hatta, 1959). The word "state-controlled" does not mean the government holds all control. The government does not intervene in economic activity but has the function of issuing policies aimed at developing the 
people's economy and protecting the people from private capital that leads to economic colonialism (see Hatta, 1973 and Hatta, 1977).

Divinity. Mohammad Hatta's commitment in running the Islamic Shariah influenced his thinking about the economy. As illustrated in the quote one of Mohammad Hatta's writings follows:

"...how man returns to the presence of God after his death brings nothing, other than a shroud wrapped in his body. All the treasures he acquired in the world left him as a stock of other human life. This is a show that the world belongs to Allah and is made solely for the abode of various derivatives" (Hatta, 1957).

According to Mohammad Hatta (1957) all forms of property, including assets and profits derived from the proceeds of true business belongs to Allah (Moslem's God) because there is an element of responsibility for all forms of business that have been done by humans. The system of capitalism sees property as part of the human self and man has full power over his possessions. There is no element of accountability to anything. This way of looking at greeds the nature of greed in man and makes it continually enrich without thinking of life after death.

Mohammad Hatta (1957) sees that property is used as a gift from Allah for man to be able to live in the world and must be distributed fairly and equitably. Equitable justice is the nature of man as a form of brotherhood and gives high value to himself and man living with him as God's creature in accordance with the teachings of Islam (Hatta, 1967). Democratic economy sees the advantages of property received by humans should be used as the driving wheel of the economy of the society in which people live (Hatta, 1935). Through this thought Mohammad Hatta (1935) assumes that the economy should be about regulating the human life in satisfying the necessities of life and increasing prosperity together which is then accountable to the owner of the true property of Allah.

Since 2005 the International Standard of Financial Reporting / IFRS name has emerged as a revolutionary breakthrough in accounting. IFRS is the result of the Lisbon treaty made by the EU on the development, guiding principles, and constitutional objectives. Such development is included in the social, cultural, political and economic fields. Under the agreement, the EU must work to develop an economic market that targets social performance and processes (Palea, 2015). IFRS was implemented and introduced by the European Union through European Parliament and Council Regulation 1606 of 2002 which appointed International Accounting Standards Board (IASB) as its designer (Palea, 2015). The mandatory of Regulation number 1606 of 2002 is to account for the accounting languages at European level in a set of high quality global standards that can be adapted by international capital markets (Palea, 2015).

Indonesia is one of many countries "forced" to adopt IFRS due to the pressure of international legitimacy (Hamidah, 2015). Adopting a global standard is considered a good deal if it talks about efficiency, but unfortunately is not able to solve problems of justice (see Mubyarto et al, 2014: 3). The public actually easily justifies that IFRS is built on the interests of the state of capitalism if it relies on the findings of Palea (2015), Gray's (1988) finding of cultural findings, Cieslewicz (2014) findings on institutional and accounting relationships, and human interests ( egoistic, materialistic, and utilitarian ) on the creation ofTriyuwono's findings (200 6). The public can also see from the composition of IASB members consisting of high-ranking public accountant firms and industry-owned capitalist countries (IASB, 2017). The attempt to filter capitalism in accounting adopted is to look at its separation slit.

Accounting and capitalism are two things that are not easily separated. These two things are metaphorically like a coin. The Chiapello (2005) study found that accounting is the beginning of the birth of the idea of capitalism. Chiapello (2005) examines the "debates" that emerged after the birth of Sombart's writings (1863-1941); a historian, economist, and sociologist of the German who wrote of the origins and development of capitalism entitled $D e$ Moderne Capitalism (see Shadilly 1987: 325). Sombart declares that accounting and capitalism are two things that can't be separated neither form nor context.

For Sombart (in Chiapello, 2005), accounting systems evolved in the direction of the developmental history of capitalism. Capitalism is born by accounting, while accounting 
evolves with the needs of this system from time to time. The five hypotheses include the "clarify" concept of "accumulation", concept of "rationalization on commerce", concept "system", and concept "separation of the business and its owner".

These five hypotheses are denied by the arguments of Yamey, Winjum, Karl Marx, and various other economists (in Chiapello, 2005) who see that historically, the notion of capitalism existed before accounting was invented. Especially Marx who defines capital without using the term accounting. In addition, accounting is considered to follow the theoretical basis, belief, and economic system of its users. For example, when accounting was popularized by mathematician-religious named Pacioli (1445-1517). In the beginning he used Double Entry Bookkeeping / DEB as gratitude to God. In the rest of the world and at other times, the 6th century accountancy was used in Arabic during the Caliph Umar Bin Khatab $(636 \mathrm{M})$ as the recording of salaries, zakat and taxes for non-muslims ( known as jarridah or zournal in Venice ). In Islamic concepts, accounting is used as a form of human worship to God (See Nurhaya ti, 2014: 56-57; Triyuwono, 2006; and Triyuwono, 2012 ). Seeing the split apart from the side of history and ideas, accounting has a large space to modify.

This study sees the urgency of deconstructing financial reporting objectives for various reasons. The first reason, the uniformity of financial reporting standards is a form of constitutional imposition of a country to be subject to international rules regardless of cultural background, state system, beliefs, and economic system. According to Cieslewicz (2014) it is difficult to uniform financial reporting standards due to several factors. One of the factors is the cultural factor of the country and the historical background of the country. The second reason is the discrepancy between the foundations of knowledge believed by the capitalist system in the making of financial reporting objectives with the people's economic system adopted by Indonesia (See Mubyarto 1987: 5 and Mubyarto et al 2014: 3). As Mubyarto (1987: 5) says that there must be a consistency of economic practice with the underlying science. So there is no "copying" the negative part of the capitalist system into the people's economic system (referring to Cieslewicz, 2014).

The most ideal way is to deconstruct the adoption process of global financial reporting standards that have occurred in Indonesia. The study finds that the most appropriate part to be deconstructed is the financial reporting objectives contained in the conceptual framework of PSAK 1.01, 1.02, and 1.10. This study is trying to eliminate the values of capitalism that is in it, hereinafter incorporating new values from the populist economy. This study divides the purpose of financial reporting into two sub-discussions namely the purpose of financial reporting based on the function (object) and its users (subject).

Financial Reporting Objects. An explanation of the elements of the financial reporting object may actually be found within the conceptual framework of PSAK 1.01 and 1.12 cited as follows:

"The purpose of general purpose financial reporting is the basis of the Conceptual Framework. Other aspects of the Conceptual Framework concept of reporting entities, qualitative characteristics, and constraints, useful financial information, elements of financial statements, recognition, measurement, presentation, and disclosure-flow logically from their objectives"(Conceptual Framework PSAK 1.01).

"General purpose financial statements provide information about the financial position of the reporting entity, which is information about the entity's economic resources and claims against the reporting entity. The financial statements also provide information on the impact of transactions and other events that alter the economic resources and entity claims. Both types of information provide useful input for decision making regarding the provision of resources to entities. "(Conceptual Framework PSAK 1.12)

Based on the above quote the user can understand the function of financial reporting. Users use the financial statements as a source of information about the entity covering economic resources and transactions conducted by the entity in which it will change the form of those resources. From the information the user can learn many things including the constraints and potential that will be presented by the entity. So users can provide input and decisions about the entity. 
The nature of this function when associated with a democratic economic system is considered not tangent. The reason is in building the economy, Indonesia needs physical information that can be learned by various types of users. The current financial reporting is considered to accommodate all types of people to learn the entity. Reflecting on the spirit of deconstruction to keep the constructs considered to be no problem, then this part of physical function is maintained.

Financial Reporting Subject. The subject of financial reporting discusses who to whom the financial reporting is intended. Subjects became a major concern in this study. Researchers see that the placement of investors, defined in the phrase "current investors and potential investors, lenders, and other creditors" dominates the conceptual framework of PSAK which speaks volumes about the purpose of financial reporting. Democratic economic sees it as a dominance that destroys the balance. Such dominance is broken down using the values contained in the system.

The concrete description of the pattern of deconstruction in this study can be seen in the following figure:

Democration Economic's Value

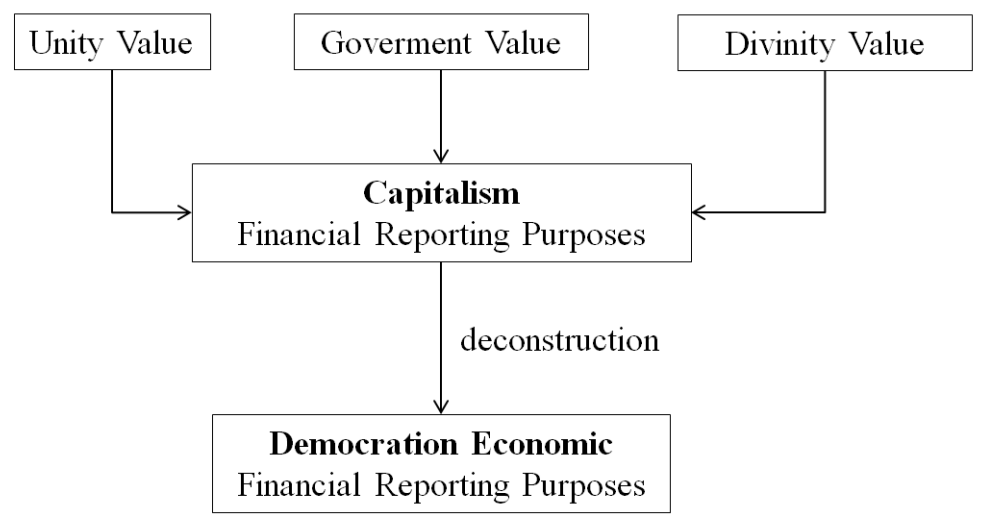

Figure 1 - Deconstruction of Financial Reporting Objectives

Figure 1 shows the fusion pattern of democratic economy premise: unity, governmental role, and divinity. This Premise is merged with the premise of capitalism about the separation of socioeconomic class, the omission of the role of government, and the objectivity of all ownership without God. Through this pattern will be found new subjects of financial reporting users.

Unity Construct. The unity of the socio-economic class is one of Mohammad Hatta's ideals to combat crisis and colonialism. The social classes that have been formed are fettering the people in a rope of dependence and eliminating the creation of social justice and common welfare. reflected in article 1 of the 1945 constitution of article 33: The economy is constituted as a joint effort based on kinship (Hatta, 1933a).

IFRS version financial reporting objectives reflect the separation of individual socioeconomic and moral classes. This can be examined through sentences written within the conceptual framework of PSAK 1.02 and 1.10 below:

"The general purpose financial reporting is to provide financial information about the reporting entity that is useful to current investors and potential investors, lenders and other creditors in making decisions about the provision of resources to the entity. Such decisions include the purchase, sale or ownership of equity instruments and debt instruments, as well as the provision or settlement of loans and other forms of credit. "(Conceptual Framework PSAK 1.02).

"Other parties, such as regulators and the public other than investors, lenders, and other creditors, can also benefit from general purpose financial statements. However, the report is not primarily addressed to the other party "(Conceptual Framework PSAK 1.10) 
Focusing on this, researchers found some of the difference underlying researchers to deconstruct. Constructs that are considered to be differences are the values contained in the different objectives of financial capitalist reporting, lacking, and inconsistent with the essence of popular economic thinking about unity. The difference found can be seen in table 1 below:

Table 1 - Difference of socio-economic class unity

\begin{tabular}{|c|c|c|}
\hline $\begin{array}{c}\text { Difference } \\
(\text { GAP) }\end{array}$ & Democratic Economic & Conventional Economic \\
\hline Definition & $\begin{array}{c}\text { The community is divided into roles as producer, } \\
\text { distributor class, and consumer group }\end{array}$ & $\begin{array}{c}\text { Society is divided into large classes of } \\
\text { capital and working class }\end{array}$ \\
\hline Moral & Justice & Efficiency \\
\hline Aim & Common Prosperity & Profit \\
\hline Objects & People & Financiers \\
\hline
\end{tabular}

Researchers found some symptom of neoclassical theory elements in the purpose of financial reporting so that there difference. The writing of sentences "are useful to current investors and potential investors, lenders and other creditors in making decisions about the provision of resources to the entity" on the conceptual framework of PSAK 1.0 is perceived as the main object in financial reporting. The word "useful" means "useful, bring good to...". Phrase "...current investor and potential investors, lenders, and other creditors..." is narrowing the scope of the object in order of financial reporting. Phrase "... making decisions about providing resources to the entity" is axiology usefulness of financial reporting. The initial perception that can be extracted from this sentence is: financial reporting is addressed to investors to make decisions about capital.

Narrowing of the scope of the object is reinforced in the conceptual framework of 1:10. in part it was found the sentence "...investors, lenders, and other creditors.." as the subject, and the phrase "...not mainly addressed to the other party" as a caption. This sentence creates a perception that: financial reporting is made not to parties other than the investor. Based on the explanation above, the researchers mapped the reader's perception of the role of the investor's financial statements as follows:

The perception of investors 1: Financial reporting is addressed to investors to make decisions about capital.

The perception of investors 2: Financial reporting is made not to parties other than the investor.

Conclusion: The other party cannot use the financial reporting in making decisions about capital.

From it, the researchers gain an understanding of the concept that financial reporting can only be used by the investor. Other parties who wish to use such information can not directly use it except using information other than financial reporting. Symptom shows partiality to the financial reporting on one hand. If it is associated with the neoclassical theory, then this sentence is applicable on individualism and personal welfare/class of its own.

Orientation financial reporting is also available from the financial reporting purposes. This orientation can be found in the elements of financial reporting. The elements of financial reporting can be found on the conceptual framework section 4, one of which discusses the company's performance. The focus of this study on conceptual framework PSAK 4:04 and 4:24 are applicable to the neoclassical theory of economic objectives.

"The financial statements portray the financial effects of transactions and other events that fall into several major groups according to their economic characteristics. A large group of these are elements of the financial statements. The elements directly related to the measurement of financial position in the statement of financial position are assets, liabilities, and equity. While the elements related to performance measurement in the income statement are income and expenses. Statement of changes in financial position usually reflects elements of the income statement and the changes in the elements of the balance 
sheet; thus, ED this Conceptual Framework identifies no elements in the statement of changes in financial position in particular. "(PSAK conceptual framework 4:04)

"Profit is frequently used as a measure of performance or as the basis for other sizes such as investment returns (return on investment) or earnings per share (earnings per share). The element that is directly related to the measurement of profit is income and expenses. The recognition and measurement of income and expenses, and profit, depends in part on the concepts of capital and capital maintenance used entities in preparing their financial statements. "(PSAK conceptual framework 4:24)

Sentences in conceptual PSAK 4:04 and 4:24 lead to a new perception of the financial reporting purposes. Analysis as follows:

The perception of investors 1: Financial reporting is addressed to investors to make decisions about capital

Perceptions of profit 1: financial reporting forming elements are two types of reports. Statement of financial position to measure the financial position and statements I aba loss to measure performance

Perceptions about income 2: Gain is a measure of the performance of the company as capital returns

Perceptions about income 3: Profit and related capital

If the merger between the perception of investors first, profit first, profit second, and profit 3 then readers of the financial statements will have a new perception that: Financial reporting is addressed to investors to make decisions about capital with reciprocal form of profit, where profit is the information in measuring performance.

This perception is the premise of the neoclassical theory of the object and purpose of financial reporting in accordance it's construct with democratic economic theory about the value of unity. First, narrowing the scope of the usefulness of financial reporting for investors just cause classification. Financiers are considered as the class that has the power of capital and decision to reciprocal form of profit.

Decision glasses democratic economic capital is the dominance of the production arrangement (specify and create the factors of production), distribution (selling), and consumption (enjoying profit). The dominance of this kind would create a socio-economic classes. So there should be clarity and division of roles in it. In neoclassical theory, the economy is the domination of the financiers' role in controlling workers. However, the economic role of the people's economy is divided into three namely the production community and workers as producers and traders as a distributor. Financiers' location is outside a production decision. Its task is to prepare a capital and production factors with reciprocal results already agreed. Furthermore, manufacturers, distributors, and financiers acting as a consumer savor the following production profits are equitably shared.

To that end, the writing proper financial reporting purposes to describe business conditions in the democratic economic spectacles related to economy class unity is as follows:

General purpose financial reporting to provide financial information reporting entity related activities of production, distribution, and consumption that are useful for the parties involved in the entity. The information in financial reporting as well as the distribution of the results of operations for the entity as part of the development workers as a major part of movement activities of the entity, the public in the environmental entities, and financiers consisting of potential investors, lenders, and other creditors in the provision of resources to the entity.

Government Constructs. Financial reporting does not accommodate the interests of the government in making goal. According to neoclassical theory perspective, the government is outside the economic system and the destroyer of the market order if do intervention. The separation between government and business set out in the conceptual framework of 1:10 as follows:

"Others, such as regulators and the public other than investors, lenders, and other creditors, too, can benefit from the general purpose financial statements. However, the report is mainly addressed to the other party "(SFAS conceptual framework 1.10) 
Financial reporting is not designed to provide special benefits for the regulator (in this case the regulator is a government). A discussion of the role of government in the conceptual framework of SFAS only teletak on grants (see conceptual framework 3:16 and 4:13). The government only got a meager portion for financial reporting.

Researchers found difference between neoclassical theory and social economy associated with a portion of the government's role in the financial reporting, the summary can be seen in table 2 below:

Table 2 - Difference Role of Government

\begin{tabular}{|c|c|c|}
\hline $\begin{array}{c}\text { Difference } \\
(G A P)\end{array}$ & Democracy Economic & Conventional Economic \\
\hline Definition & $\begin{array}{c}\text { The government is a regulator and } \\
\text { provider of economic policies }\end{array}$ & $\begin{array}{c}\text { The government is the regulator and providers of legal } \\
\text { policy, politics, and other matters beyond economics }\end{array}$ \\
\hline Moral & paternalism & there is no \\
\hline Aim & Set the course of economy & there is no \\
\hline Objects & Material, social, cultural, and political & Material \\
\hline
\end{tabular}

The government's role is very small if the readers of the report see the conceptual framework. Design of financial reporting conceptual framework for the government was minimal. The phrase "appropriate representation" describes the entity that will only make a report to the government is, or even memorable underestimated. Whereas democratic economy puts the government in a very large portion. Mohammad Hatta stressed that the production branches which are important for the people and serving the people controlled by the state. That is, the government as well as investors, requires the same level of information but with a different measurement points. As supporting information, the reports provided to the investors and the government must be in a form that is made by the company. To support this it is necessary to set in financial reporting purposes.

Researchers believe there needs to be a sentence that clearly demonstrates the usefulness of financial information against the interests of the government. However, not the government is not directly involved in the business. Back to PSAK 1:10, the phrase "other parties, such as regulators in addition to workers, the public, investors, lenders, and other creditors" will be retained to emphasize the separation of government business. It should be added the phrase "... benefit from the financial statements. Financial reporting should provide information that is useful to the regulator..." to made clear that the government also needs information that is equally important in monitoring and set policy. With the existence of this sentence, the entity is certainly obliged to provide the information required by the government.

Therefore, in the financial reporting purposes, there must be democratic economic version of the following points:

Other parties, such as regulators in addition to workers, the public, investors, lenders, and other creditors can savor the financial statements. Financial reporting should provide information that is useful to the regulator with regard to policy administration, enforcement, and supervisor of the entity to remain in the economical goal of prosperity and justice for all Indonesian people.

Divinity Constructю Value God played a role in the thinking of Mohammad Hatta on social economy. Democratic economy comes from the spirit of collectivity, justice, and the spirit of brotherhood. Those values born from Islam about togetherness. Indonesia is a collective society, rooted in the high customs, and develop in accordance with the demands of modern times. This trait then becomes the origin and the birth of the spirit of gotong royong (Indonesian motto of togetherness) (Hatta, 1979).

According to Mohammad Hatta (1967) gotong royong is the original nature of Indonesian society. Gotong royong contained in the common values that see that economic activity should give priority to cooperation between people in a family atmosphere, free from oppression and coercion. Economic activity must respect the man as a creature of God accountable. Accountability includes himself to the owner of the world, namely, God, family 
and society as well as in the environment. This trait became one of the foundations of a democratic economic textual written in the 1945 Constitution article 33, paragraph 1.

Readers of the financial statements will not be able to find the word "God" in the conceptual framework, especially in financial reporting purposes. For adherents of neoclassical, God is in the home, not on the market. The nature of God for the capitalists is private. The relationship between man and God is limited to worship, while the economy is the relationship between humans and other humans. Neoclassical understanding of God be contrary to the people's economy which raises the difference which are summarized in Table 3 below:

Table 3 - Difference Divinity

\begin{tabular}{|c|c|c|}
\hline Difference (GAP) & Economic Democracy & Conventional economics \\
\hline Definition & God is the center of accountability & God is a private affair of man outside market \\
\hline Moral & Wahyu illaiyah (Divinity) & there is no \\
\hline Aim & Worship & there is no \\
\hline Objects & Human & there is no \\
\hline
\end{tabular}

Democratic economic has a strong bond with God. In contrast to neoclassical theory born from the observation of demand and supply, as well as socialist theory born from the pressure of social class. Economic precisely Mohammad Hatta was born from the need to implement the right economic pattern based on religion that he had faith. Democratic economic be redefined by Mubyarto as Pancasila economy also have the same confidence, that the main moral economy in Indonesia is revelation (Mubyarto, 1987: 53).

God's role in the economy has two things to be basic. First, the business is part of the worship of mankind who will be accountable to God. Second, the business humanizing as a real form of brotherhood. Thus, the financial statements must be able to provide information that remains to describe the lawful and unlawful business enterprise. Reporting no longer allowed to make man as an expense deduction from earnings.

For the purpose of financial reporting should be a relevant passage illustrates the necessity of companies to remain in the hall and away from the ban command of God. Alenia contains sentences that describe the presence of God in the entity, referrals to do business according to the commandment of God, and God as the center of the accountability. So one of the objectives of financial reporting are:

Special purpose financial reporting as an entity in the main control ensures the operation of activities in accordance with the values of divinity. Financial reporting is the embodiment of the assets given responsibility in the form of earth, water, and everything contained in it.

Embodiment Consequencesю The researchers offer some of the consequences that can be from the community economy financial reporting purposes, even though this nature is an alternative form, so it is not an absolute to follow. There needs to be further development be it in the form of research and application.

The first consequence is the orientation of the company's performance. Democratic economy adjust more aspects than just conventional economic organize the material. Democratic economic organize the material, social, cultural, and political. Thus, with a economic democratic financial reporting purposes, the company's performance is not only measured by profit. But the size of social justice and political measure. Financial reporting will have several new reports in addition to the income statement. There are reports of social and justice for measuring the welfare of workers and the surrounding community. There are reports that it set policy on matters related to the information required by local and national government in terms of supervision. During this time no other reporting set 2 things,the CSR report and fiscal reports for tax reconciliation, unfortunately two separate reporting and voluntary nature. The form of reports that regulate the social, cultural, political and still need to be considered and investigated further.

A second consequence is positioning human. Democratic economy put God at the center of responsibility. As the form is subject to God, humans are obliged to respect other 
human beings. Financial reporting can no longer put a man as a burden because it is a form of dehumanization of human beings into objects and economic animal (see Sitorus, 2015; Triyuwono; 2006b).

The final consequence is awareness on all sides about the dogma of neoclassical economics that are grown and rooted firmly. This study is a prod to examine other aspects in accounting and economics in Indonesia which is already irrelevant to the nation's economic objectives. The studies both in the field of academics and practitioners. Economic democratic development that creates a modern and more weight as the nation's ideals officials such as Mohammad Hatta, and scholars such as Mubyarto and Baswir: restoring economic goals of Indonesia to create wealth and prosperity with justice.

\section{CONCLUSION}

The purpose of financial reporting used as the basis for the formation of financial reporting standards. This is reflected in the conceptual framework of International Finance Reporting Standards / IFRS which was later adopted in Indonesia as Pernyataan Standar Keuangan/PSAK (Statement of Financial Accounting Standards in Indonesia). The main component of global financial reporting standards is the European Union and the countries of the Anglo-Saxon majority sensible liberal political and capitalism. The problem is that Indonesia has a democratic economic system which is the antithesis of capitalism. The research looked global standards as a form of modern economic imperialism. Part troubled in financial reporting standard is the purpose.

This research is trying to find alternative forms of financial reporting purposes in accordance with Indonesia. Alternative form used is the economic democratic perspective promoted by Mohammad Hatta. The premise of the people's economy used as a deconstruction of the financial reporting purposes resulting from Mohammad Hatta's literature.

From the literature study obtained democratic economic premises are unity, the role of government, and the value of God (divinity). Premises are used for deconstructing financial reporting purposes form. This deconstruction does not completely eliminate the old constructs to maintain constructs that are deemed relevant to the democratic economic. This research resulted in a financial reporting form that presents financial information with the aim of providing a sense of unity that accommodate the needs of economic policy information and means of worship to the Lord for the entity, workers, governments, and investors.

\section{REFERENCES}

1. Baswir, Revrisond. 2009. Ekonomi Kerakyatan sebagai Sokoguru Perekonomian Nasional. Yogyakarta: Universitas Gadjah Mada

2. Chiapello, Eve. 2005. Accounting and the birth of the notion of capitalism. Critical Perspectives on Accounting 18 (2007) 263-296

3. Creswell, J.W. 2007. Qualitative Inquiry and Research Design. California: Sage Publication Inc

4. Europan Comunities. 2002. Regulation No 1606/2002. Official Journal Of Europan Communities

5. Gray, S.J., 1988. Toward an Undertanding of Cultural Influence on the Development of Accounting Systems Internationally. Abacus, 24(1), pp. 9-11, 12

6. Hamid, Edi Suandi. 2009. Akar Krisis Ekonomi dan Dampaknya Terhadap Indonesia. Jurnal Ekonomi Islam Volume III no 1

7. Hamidah. Iwan Triyuwono. Eko Ganis Sukoharsono. Ali Djamhuri. The Hegemony of International Interests on IFRS Adoption in Indonesia: an Accounting Ecology Perspective. Procedia - Social and Behavioral Sciences 211 ( 2015 ) $104-110$

8. Shadily, Hassan. 1987. Ensiklopedi Indonesia Jilid 6 (SHI-VAJ). Jakarta: Ichtiar Baru-van Hoeve.

9. Hatta, Mohammad. 1931. Ekonomi Syarka dan Khaddar alias Politik Perekonomian. 
Persatuan Indonesia no 79

10. Hatta, Mohammad. 1932. Soal Ekonomi dalam Persatuan Indonesia. Daulat Ra'jat no 45.

11. Hatta, Mohammad. 1933a. Nasib Kaum Dagang Kecil di Indonesia. Daulat Ra'jat no 66.

12. Hatta, Mohammad. 1933b. Ekonomi Rakyat. Daulat Ra'jat no 79.

13. Hatta, Mohammad. 1933c. Perjuangan Buruh. Daulat Ra'jat.

14. Hatta, Mohammad. 1934. Krisis Ekonomi dan Kapitalisme. Brosur.

15. Hatta, Mohammad. 1935. Ekonomi dan Kemakmuran. Digul dan Neira.

16. Hatta, Mohammad. 1956. Ekonomi dan Masyarakat. Sambutan pada resepsi Kongres Ikatan Sarjana Ekonomi Indonesia (SEI)

17. Hatta, Mohammad. 1957. Sosialisme di Indonesia. Pidato di depan mahasiswa Universitas Sun Yat Sen di Kanton.

18. Hatta, Mohammad. 1967. Masalah Bantuan Bagi Perkembangan Indonesia. Kata Pengantar "Beberapa Pokok Pikiran" yang diterbitkan tahun 1992.

19. Hatta, Mohammad. 1977. Pelaksanaan Pasal 33 UUD 1945. Pidato di depan Seminar Penjabaran Pasal 33 UUD 1945, 6-7 oktober 1977

20. Hatta, Mohammad. 1979. Pengembangan Pengusaha Kecil: Salah Satu Aspek Ekonomi Terpimpin. Sambutan Pada Pelantikan Badan Pimpinan dan Daerah HIPKI Sumatera Barat di Padang.

21. Imran, Amrin. 1991. Mohammad Hatta: Pejuang, Proklamator, Pemimpin, Manusia Biasa. Jakarta: Mutiara Sumber Widya

22. Ikatan Akuntansi Indonesia. 2016. Pernyataan Standar Akuntansi Keuangan.

23. International Accounting Boards. 2012. International Financial Reporting Standards.

24. International Accounting Boards. 2016. IASB Board membership. Diakses pada tanggal 23 mei 2017 dari: https://www.iasplus.com/en/resources/ifrsf/iasb-ifrs-ic/iasb-board

25. Kamayanti, Ari. 2016. Metodologi Penelitian Kualitatif Akuntansi. Jakarta: Yayasan Rumah Peneleh

26. Kennedy, 2009. Adam Smith and the Invisible Hand: From Metaphor to Myth. Econ Journal Watch Volume 6, Number 2 May 2009, pp 239-263

27. Ludigdo, Unti dan Ari Kamayanti. 2012. Pancasila as Accountant Ethics Imperialism Liberator. World Journal of Social Sciences Vol. 2. No. 6. September 2012 Issue. Pp. 159 $-168$

28. Moleong, L. J. 2004. Metodologi Kualitatif. Bandung: PT Remaja Rosdakarya.

29. Mulawarman. 2012. Akuntansi Syariah di Pusaran Kegialaan "IFRS-IPSAS" Neo liberalisme: Kritik atas IAS 41 dan IPSAS 27 mengenai pertanian. Jurusan Akuntansi Fakultas Ekonomi dan Bisnis Universitas Brawijaya.

30. Mubyarto. 1987. Ekonomi Pancasila: Gagasam dan Kemungkinan. Jakarta: LP3ES

31. Mubyarto et al. 2014. Ekonomi Kerakyatan. Jakarta: Lembaga Suluh Nasional

32. Noer, Deliar. 2012. Mohammad Hatta Hati Nurani Bangsa. Jakarta: PT Kompas Media Nusantara

33. Nurhayati, Sri., Wasilah. 2014. Akuntansi Syariah di Indonesia (Edisi 4). Jakarta: Penerbit Salemba

34. O'Donnell, Kevin. 2009. Posmodernisme. Daerah Istimewa Yogyakarta: PT Kanisius (Anggota IKAPI)

35. Palea, Vera. 2015. Standardizing Financial Reporting Regulation: What Implications for Varieties of Capitalism?. Working Paper Series no. 1-5. University of Torino. Torino

36. Richburg, Keith B. 1998. "Cashing In on Years in Power". The Washington Post Company: Washington Post Foreign Service, Friday, May 22, 1998; Page A40.

37. Republik Indonesia. 1945. Undang-Undang Dasar RI 1945 pasal 33 Tentang Pengertian Perekonomian, Pemanfaatan SDA, dan Prinsip Perekonomian Nasional

38. Saharuddin. 2009. Perberdayaan Masyarakat Miskin Berbasis Kearifan Lokal. Jurnal: Sodality: Jurnal Transdisiplin Sosiologi, Komunikasi, dan Ekologi Manusia. Vol. 3 no 1

39. Sugiyono. 2012. Memahami Penelitian Kualitatif. Bandung: ALFABETA

40. Sitorus, Jordan HK. 2015. Membawa Pancasila dalam Suatu Definisi Akuntansi. Malang: JAMAL Vol 2 No 2 Halaman 175-340

41. Smith, A. 1976. An Inquiry into the Nature and Causes of Wealth Of Nations. Electronic 
Classics Series. The Pennsylvania State University

42. Turner, Jonathan H. 1981. The Emergence of sociological theory. Illinois: The Dorsey Press.

43. Triyuwono, Iwan. Ali Djamhuri. Aji Dedi Mulawarman. Darsono Prawironegoro, 2016. Filsafat IImu Akuntansi: Berpikir Kontemlatif, Holistik, Intuitif, Imajinatif, Kreatif, Rasional, dan Radikal dalam Akuntansi. Jakarta: Mitra Wacana Media

44. Triyuwono, I. 2006. Akuntansi Syari'ah: Menuju Puncak Kesadaran Ketuhanan Manunggaling Kawulo-Gusti. Malang: Pidato Pengukuhan Jabatan Guru Besar Fakultas Ekonomi Universitas Brawijaya.

45. Triyuwono, I. 2012. Akuntansi Syariah: Perspektif, Metodologi dan Teori (2 ed). Rajawali Pers. Jakarta

46. Wagiran. 2011. Pengembangan Model Pendidikan Kearifan Lokal dalam Mendukung Visi Pembangunan Provinsi Daerah Istimewa Yogyakarta 2020 (Tahun Kedua). Jurnal: Penelitian dan Pengembangan, Volume III, Nomor 3. 